\begin{tabular}{|c|c|c|c|}
\hline KULTURA & $\begin{array}{l}\text { POLSKA } \\
\text { KOMITET } \\
\text { INSTYTU }\end{array}$ & $\begin{array}{l}\text { AKADEMIA NAUK } \\
\text { SOCJOLOGII } \\
\text { T STUDIÓW POLITYCZNYCH }\end{array}$ & ISSN 0023-5172 \\
\hline & 2016, nr 1 & MIĘDZY KULTURAMI: SZKICE I & NOTATKI \\
\hline
\end{tabular}

ZUZANNA BOGUMIE

Akademia Pedagogiki Specjalnej im. Marii Grzegorzewskiej

\title{
CHŁOPSKA PAMIĘĆ WOJNY NA PRZYKŁADZIE FOTOGRAFII FELIKSA ŁUKOWSKIEGO
}

Kolekcja zdjęć Feliksa Łukowskiego ${ }^{1}$ przez znawców tematyki uważana jest za cenny dokument epoki, zapis życia zamojskich wsi w latach trzydziestych-pięćdziesiątych XX wieku. Jak pisał przyjaciel Łukowskiego, Jerzy Lewczyński (2005, s. 12), który poddał konserwacji negatywy fotografa-amatora, fotografie oddają pełniej prawdę o wyglądzie „tamtego czasu” i „tamtych dni”. Czy jednak rzeczywiście tak jest? Czy przyglądając się tym fotografiom możemy zrekonstruować i zrozumieć realia życia ówczesnej wsi zamojskiej? Lewczyński twierdził, że fotografia ma „zdolność przekazywania pamięci o przeszłości”. Czy zatem widoki uchwycone na negatywach Łukowskiego pokrywają się z tym, co zostało zapisane w pamięci świadków tamtych wydarzeń? Czy zdjęcia przybliżają nas do tamtego świata, tak dalekiego od rzeczywistości, w której obecnie żyjemy? Odwołam się tu do wybranych fotografii z kolekcji Łukowskiego i wyników badań terenowych przeprowadzonych w ramach projektu „Z kolekcji zdjęć Feliksa Łukowskiego - rekonstrukcja życia wsi w latach 40. XX wieku na Zamojszczyźnie" ${ }^{2}$, pokażę, jak dalece to, co zostało uchwycone na negatywie,

Adres do korespondencji: mitregaz@wp.pl

${ }^{1}$ Feliks Łukowski urodził się w 1919 roku. Przed wojną ukończył cztery klasy gimnazjum, po wojnie zrobił maturę. W tym czasie mieszkał w Siemnicach i fotografował ludzi oraz wydarzenia ważne w życiu lokalnej społeczności. Po wojnie pracował jako nauczyciel, został też dyrektorem szkoły. Założył rodzinę, miał syna i dwie córki. Zmarł w 1985 roku w Tomaszowie Lubelskim. Wdowa po Łukowskim przekazała negatywy Jerzemu Lewczyńskiemu, fotografowi i przyjacielowi Łukowskiego, który poddał je konserwacji. Obecnie cała kolekcja zdjęć, wraz z prawami do niej, znajduje się w Muzeum Zamojskim w Zamościu.

2 Projekt finansowany z grantu wewnętrznego Akademii Pedagogiki Specjalnej im. Marii Grzegorzewskiej, 2015-2016 (BSTP 37/15-1). Partnerem programu był Dom Spotkań z Historią. Za 
odbiega od tego, co zapamiętali świadkowie. Podejmę próbę wytłumaczenia, skąd wynika ta rozbieżność, i pokazania, w jakim stopniu socjologiczna analiza jest pomocna w określeniu sensów przez fotografię ewokowanych. Dla lepszego zobrazowania problemu posłużę się wybranymi fotografiami okresu okupacji niemieckiej lat 1939-1944.

Łukowski w ciągu dwudziestu lat wykonał około 1500 zdjęć, dokumentując przemiany zachodzące $\mathrm{w}$ jego rodzinnej wsi i okolicznych miejscowości. Na negatywach uchwycił wybrane aspekty życia okupacyjnego, proces powojennej modernizacji, pojawianie się nowych maszyn rolniczych, zmiany obyczajowe. Łukowski nie był reporterem, ale fotografem-amatorem dokumentującym to, co wydawało mu się istotne w życiu lokalnej społeczności, w większości swojej rodziny i przyjaciół. Jego zdjęcia odzwierciedlają zatem to, co dla ówczesnego mieszkańca wsi było ważne i godne zapamiętania, przez co stanowią ciekawy przykład historii mentalności. Gdyby je ułożyć chronologicznie, składałyby się na opowieść o życiu lokalnej społeczności, jej obyczajach, pracy, życiu towarzyskim i rodzinnym oraz przemianach tego życia; a raczej na opowieść o wyobrażeniu o tym życiu. Niestety, kolekcja Łukowskiego nie doczekała się pełnego opracowania, część opisów jest bardzo szczątkowa, wiele postaci nie zostało zidentyfikowanych, pozostają anonimowymi świadkami przeszłości. Trudno jest też ułożyć zdjęcia chronologicznie i ustalić ich sekwencję, gdyż obrazy na nich zapisane nie są jednoznaczne. W rezultacie rekonstrukcja życia wiejskiego i jego przemian zaczyna być mocno problematyczna. Mimo tych widocznych na pierwszy rzut oka problemów kolekcja Łukowskiego jest chętnie wykorzystywana jako ilustracja przeszłości.

Badacze materiałów wizualnych podkreślają, że fotografie są jedynie „cytatami z rzeczywistości" (Sztandara 2006, s. 7), a uchwycone przez fotografa kadry pokazują to, co ówczesny mieszkaniec wsi uznał za ważne i warte zapamiętania lub co mógł przedstawić. Sam Lewczyński (2005, s. 10) pisał o fotografiach Łukowskiego: „Są też duże luki w opisie ówczesnej epoki. Nie ma na przykład zdjęć Żydów. [...] Okupanci pokazani są tak jak to było możliwe, a więc w sytuacji gdy pozując pokazywali własną wielkość i siłę”. Zdjęcia Łukowskiego można zatem wykorzystać do odtworzenia kontekstu społecznego i kulturowego, w jakim powstały, należy jednak pozostawać czujnym wobec ich przekazu. Jak bowiem zaznacza Janina Struk (2007, s. 35): „Fotografie są fragmentami. Ilustrują historie, lecz ich nie opowiadają”. Są dowodami przeszłości, ale — jak każde źródło - nie są obiektywne, stąd konieczność krytycznej ich analizy.

Fotografie archiwalne zarówno w dyskursie historycznym, jak i potocznie traktuje się jako świadectwo - dowód, że pewne wydarzenie miało miejsce. Jak pisze Roland Barthes (1995, s. 32): „W wypadku Fotografii nigdy nie mogę

udział w badaniach terenowych dziękuję Ewie Mazur, Marii Buko, Łukaszowi Kamińskiemu, Jarosławowi Pałce. 
zanegować faktu, że ta rzecz tam była. Jest podwójna wspólna płaszczyzna: realność i przeszłość". Oddzielny problem stanowi kwestia, co tak naprawdę przedstawia dane zdjęcie. Jak zauważa cytowana wcześniej Janina Struk (2007, s. 35): „teraźniejszość zawsze wywiera wpływ na rekonstrukcję przeszłości”, to, jak ją rozumiemy i w jaki sposób odczytujemy fotografie archiwalne, zależy od narracji, jaką im nadadzą kustosze, propagandyści czy historycy, w tym ci pracujący w archiwach. Wydaje się, że w przypadku fotografii archiwalnej problem nadawania jej sensu przez osobę ją posiadającą/opisującą jest jeszcze bardziej widoczny, a słowa Barthesa (1995, s. 23), że: „fotografia przekształca podmiot w przedmiot, a nawet, można powiedzieć, w przedmiot muzealny", jeszcze bardziej adekwatne. Proces ten doskonale obrazuje dotychczasowe podejście i sposób prezentacji fotografii Łukowskiego.

W przypadku zdjęć Łukowskiego krytyczne podejście jest tym ważniejsze, że jego kolekcja dokumentuje nie wielką historię, ale historię małej zbiorowości ludzkiej, mieszkańców Siemnic i okolicznych miejscowości na Zamojszczyźnie. Michel Foucault (1998) twierdzi, że historia zwycięzców, wielka historia jest dokumentowana $\mathrm{w}$ kronikach, archiwach i muzeach, problem stanowi przeszłość grup marginalizowanych, których pamięć nie jest utrwalana na instytucjonalnych nośnikach. Wiedza o takiej grupie i jej doświadczeniach uchodzi $\mathrm{w}$ niepamięć. Wynika to $\mathrm{z}$ faktu, że ich historia nie jest historią ciągłości mającą swoją genealogię, ale historią przecięcia, zerwania. Istniejące źródła historyczne są niekompletne lub niedostatecznie opracowane, dlatego z czasem mogą stać się niezrozumiałe dla odbiorcy. Dlatego tym cenniejsza jest kolekcja zdjęć Feliksa Łukowskiego. Gdyby nie te zdjęcia historia przedstawianych na nich wsi uległaby całkowitemu zapomnieniu. Dlatego właśnie tak ważne jest zrozumienie tych fotografii, zarówno uchwyconych widoków, jak i filozofii, która przyświecała fotografowi, gdy decydował się na poszczególne ujęcia. Łukowski fotografował bowiem tradycyjne życie wiejskie, a jak pisał Lucien Febvre (cyt. za: Szacki 2011, s. 235), „społeczeństwa tradycyjne uporządkowały swą przeszłość urzędowo i pragmatycznie. Biorąc za punkt wyjścia wyobrażenia, jakie miały o swym życiu obecnym, o swoich celach zbiorowych, o cnotach niezbędnych dla ich osiągnięcia, uczyniły z przeszłości coś $\mathrm{w}$ rodzaju prefiguracji tego wszystkiego". Rodzi się zatem pytanie, co tak naprawdę przedstawiają negatywy Łukowskiego. Czy jest to zapis historii czy może tradycji? Zapis zmiany i płynności czy może trwania?

\section{PROBLEMATYCZNOŚĆ SPOSOBU PREZENTACJI ZDJĘĆ}

Fotografie Feliksa Łukowskiego były dotychczas traktowane przede wszystkim jako źródło wiedzy o przeszłości i prezentowane jako dokumenty ilustrujące życie wsi zamojskich przełomu lat trzydziestych-pięćdziesiątych XX wieku. W ten sposób zaprezentowano je zarówno w wydanym w 2005 roku w Zamościu albumie Świat chatup, stodót i optotków. Wieś w obiektywie Feliksa Łu- 
kowskiego z Siemnic, pow. Tomaszów Lubelski. Fotografie z lat 40. i 50. XX wieku, jak i na wystawach: „Było to 50 lat temu” (w Muzeum Zamojskim w 1992 roku), „Ocalone wspomnienia. Fotografie Feliksa Łukowskiego” (w Akademickim Centrum Kultury „Chatka Żaka” w Lublinie w 2009 roku) oraz „Wojenne ślady dwóch fotografów. Dwie perspektywy Kurta Goldmanna i Feliksa Łukowskiego" (w Instytucie Pamięci Narodowej w Lublinie w 2010 roku). Takie wykorzystanie fotografii - jako ilustracji wiedzy kuratora czy historyka o przeszłości - pociąga jednak za sobą problemy metodologiczne. Pozbawione historycznego i kulturowego kontekstu fotografie pozostawały nieme, każdy mógł nadać im własny sens, gdyż — jak podkreślają badacze materiałów wizualnych - fotografie same w sobie mówią tylko tyle, że to, co przedstawiaja, wydarzyło się, nie nadają jednak sensu tym wydarzeniom. Fotografia jest, jak pisze Magdalena Sztandara (2006, s. 8): „[...] odzwierciedleniem rzeczywistości, próbą jej zapisu i subiektywnym przedstawieniem jej wykonawcy; jest i realistyczna i konwencjonalna. Podlegać więc musi złożonym interpretacjom na trzech poziomach: indywidualizującym — jest zapisem wyobrażeń i wrażliwości kierującego się postawą subiektywizmu artystycznego twórcy, czyli fotografa; kulturowym - pozostaje przecież obrazem zależnym od sytuacji kulturowej i przyjętego kodu; poznawczym - jest wszak obrazem odsyłającym do istniejącej poza nim rzeczywistości i o niej orzekającym”.

Dotychczas nikt nie podjął się tak złożonej interpretacji kolekcji zdjęć Feliksa Łukowskiego. Doskonałym przykładem jej wykorzystywania jest album z 2005 roku, którego zarówno tytuł Świat chałup, stodót i opłotków, jak i tematyczny podział na takie działy jak: Autor, Dzieci, Panny, Kawalerka, Wesele, Razem, W domu i przy pracy, Pogrzeby, Wojna, Po wojnie, Portrety, pokazuje, że redaktorom tomu nie udało się uciec od potraktowania fotografii jako „antropologicznych typizacji”. Wobec fotografowanej przez Łukowskiego rzeczywistości stosują „spojrzenie etnograficzne”, a więc wybrali te widoki, które stanowią rodzaj „pocztówek z życia ludowego”, zawierają kadry tego, co wydaje się zwykłe i codzienne, dzięki czemu zdobywają status autentycznych, naturalnych i posiadających szczególną wartość (Sztandara 2006, s. 80). Jednak taki sposób patrzenia, jak pokazuje Sztandara, nie jest ani oczywisty, ani obiektywny, ale stanowi rezultat wpływu ukształtowanych w XX wieku stereotypów i wyobrażeń dotyczących życia chłopów.

Inny problem widoczny $\mathrm{w}$ dotychczasowym sposobie prezentacji zdjęć Feliksa Łukowskiego nasuwa fakt, że zdjęcia, które dla fotografa były zdjęciami prywatnymi, są przedstawiane jako fotografie publiczne, przez co zmienia się ich status ontologiczny. Łukowski fotografował swoich sąsiadów, rodzinę i znajomych, jego zdjęcia są dziś jednak przedstawiane z pominięciem tego kontekstu - jako fotografie publiczne, pozbawiające uwiecznionych na nich ludzi „imion własnych” (Sikora 2004, s. 11), a więc ich jednostkowości i niepowtarzalności. Z wyjątkiem starszych wiekiem mieszkańców Siemnic i okolic, którzy jeszcze potrafią rozpoznać niektóre sfotografowane osoby, przedstawione 
na zdjęciach postaci niewiele mówią osobom dziś je oglądającym. Osoby na zdjęciach są po prostu reprezentantami pewnej grupy chłopów. Sprawia to, że — używając słów Sławomira Sikory (2004, s. 17) — „mamy [...] do czynienia $z$ przesunięciem pomiędzy odniesieniem rzeczywistym (tym, a nie innym człowiekiem czy przedmiotem) a [...] «odniesieniem idealnym»: oto Człowiek, jakiś Typ człowieka, przedstawiciel jakiejś grupy [...]". Odarte z pierwotnego sensu zdjęcia Łukowskiego jedynie informują, przedstawiają pewne wydarzenia. Jak pisze John Berger (1999, s. 82) „publiczna fotografia [...] jest wyrwana z kontekstu i staje się martwym przedmiotem, który - właśnie z powodu tego, że jest martwy - może zostać arbitralnie wykorzystany". W ten sposób są przeważnie przedstawiane zdjęcia Łukowskiego.

Przy prezentacji zdjęć Łukowskiego dotychczas nie zwracano też uwagi na fakt, że są one przykładem fotografii chłopskiej, czyli takiej, która powstała na życzenie i z inicjatywy samych chłopów, przez co została wykonana według pewnego kanonu i z zastosowaniem estetyki chłopskiej. Fotografia chłopska jest dokumentem obrazującym przede wszystkim kulturę wsi, oddaje jej wewnętrzny charakter to, co było najistotniejsze dla tej kultury, a więc rodzinę i zwyczaje związane $z$ jej funkcjonowaniem (Bartuszek 2005). Ten nacisk położony na uchwycenie specyfiki kultury, a nie skrupulatny zapis wydarzeń historycznych jest bardzo istotny w przypadku zdjęć Łukowskiego. Zostały wykonane przez chłopa-fotografa. Są to zatem fotografie, które mówią o chłopskim postrzeganiu świata (por. Garlicka 1993). Fotografie Łukowskiego są zatem nie tylko ilustracją dziejów, ale są zapisem indywidualnych cech rodzin chłopskich, ich życia, kultury i obyczajów. To w jaki sposób to życie zostało uwiecznione, wydaje się $w$ dużej mierze zgodne $z$ kanonem estetyki chłopskiej, która silnie wpływa na sposób ustawienia osób na zdjęciu i sam kadr zdjęcia.

Pierre Bourdieu (2012, s. 241), analizując stosunek różnych grup społecznych do fotografii w latach sześćdziesiątych XX wieku, zwracał uwagę, że klasy społeczne posługują się odmiennymi kanonami estetycznymi w ocenie i interpretacji zdjęć. W rezultacie nie każda fotografia jest dla wszystkich czytelna, a jedynie ta, która odwołuje się do znanych danej grupie systemów interpretacji. Co więcej, jest to fotografia, która pełni jakąś funkcję społeczną, odwołuje do systemu norm o charakterze etycznym. Fotografia, która nie odwołuje do pewnych wartości, jest bezwartościowa i może wywoływać niepokój. Ponieważ Łukowski był ceniony wśród mieszkańców Siemnic i okolic, wielu zamawiało u niego zdjęcia, należy przypuszczać, że nie naruszał kanonów estetyki chłopskiej nawet jeśli eksperymentował ze zdjęciami. Jest to widoczne przede wszystkim w sposobie prezentacji ludzi.

Bourdieu (2012, s. 248-252) zwracał uwagę na takie cechy estetyki chłopskiej jak konieczność przybrania pozy frontalnej, raczej sztywnej, sztucznej, a nie naturalnej, gdyż $\mathrm{w}$ ten sposób osoba fotografowana wyraża szacunek dla samego siebie i osoby patrzącej. Taka poza jest uważana za zgodną z kulturowo zakorzenionymi wartościami, takimi jak honor, godność, i potrzeba 
wzajemnego poważania. Widać wyraźnie, że grupowe i indywidualne zdjęcia Łukowskiego stosują się do kanonów tej estetyki. Należy więc w sposób bardziej krytyczny aniżeli Lewczyński spojrzeć na wojenne zdjęcia okupantów. W przywoływanym wcześniej cytacie pisał on: „Okupanci pokazani są tak jak to było możliwe, a więc w sytuacji gdy pozując pokazywali własną wielkość i siłę" (Lewczyński 2005, s. 10). Tyle że do zdjęć pozują nie tylko okupanci, ale wszyscy inni bohaterowie zdjęć Łukowskiego, w tym partyzanci. Ci ostatni robią to zresztą w sposób dużo bardziej ostentacyjny. Analizując zdjęcia warto zatem zastanowić się, $\mathrm{w}$ jakim stopniu przedstawienia okupantów to rzeczywiście próby ostentacyjnej prezentacji własnej wielkości, a $\mathrm{w}$ jakim rezultat założeń fotografa.

Zdając sobie sprawę z problematyczności dotychczasowego sposobu prezentacji fotografii Łukowskiego, w realizowanym przez nas projekcie postanowiliśmy potraktować je nie jako przykłady fotografii dokumentalnej, ale jako materiał socjologii wizualnej. Takie podejście miało ważne metodologiczne uzasadnienie. Jak podkreśla bowiem Howard Becker (2012), mimo że fotografia dokumentalna i socjologia wizualna rozwijały się w tym samym czasie, a obydwa typy fotografii przypominały się wzajemnie i przez długi czas różnica między nimi wynikała przede wszystkim z przestrzeni ich prezentacji, czy była to gazeta, czy czasopismo naukowe; to jednak typy te się różnią. Fotografie bowiem nabierają znaczenia w określonych kontekstach. Fotografia dokumentalna rzadko dostarcza więcej informacji niż jest na zdjęciu, widz sam musi szukać wskazówek, nadawać znaczenia zdjęciu, które to znaczenie często może być dalekie od historycznego kontekstu, gdyż ten przestał być dla widza zrozumiały. $Z$ kolei socjologii wizualnej przede wszystkim zależy na jak najpełniejszym uchwyceniu kontekstu fotografii — zarówno kontekstu wykonania zdjęcia, jak i przedstawionego na nim tematu. Istotnym elementem jest dekonstrukcja zasad estetycznego kanonu wykorzystanego przez fotografa-amatora (por. Bourdieu 2012, s. 241-243), po to by dotrzeć do istoty przedstawienia. Dotychczas zdjęcia Feliksa Łukowskiego były traktowane jako fotografie dokumentalne. W literaturze występowały również w kontekście sztuki jako część programu artystycznego „archeologia fotografii” według koncepcji Jerzego Lewczyńskiego (2005), która zakłada nadawanie znaczeń i kontekstów anonimowym fotografiom. Nasz projekt uruchamiał zatem nowe spojrzenie na tę wyjątkową kolekcję zdjęć.

Nie traktowaliśmy zdjęć Łukowskiego jako dokumentu potwierdzającego wydarzenia historyczne, ale jako rodzaj fotograficznego opisu badanej rzeczywistości, rodzaj narzędzia antropologicznej obserwacji. Jak zauważa Krzysztof Olechnicki (2003, s. 9): „Fotografia może wspomagać zarówno naukę rozumienia świata, jak i sztukę komunikowania tego, co udało się nam zrozumieć. [...] przestaje być "produktem» badań w terenie, a staje się procesem, poprzez który badacz dochodzi do zrozumienia otaczającego go świata i ludzi”. Naszym założeniem było właśnie takie wykorzystanie kolekcji Łukowskiego, po to by 
w opisie życia codziennego wsi zamojskich okresu niemieckiej okupacji, dzięki odwołaniu się do zdjęć Łukowskiego, postarać się uchwycić wątki, które nie byłyby możliwe do uchwycenia przy użyciu innych metod badawczych. Jednocześnie była to próba zrozumienia nieobecności pewnych wydarzeń na fotografiach Łukowskiego. Wydarzeń, które z pewnością miały ogromny wpływ na życie mieszkańców regionu, takich jak pacyfikacje, wysiedlenia, Holokaust, czystki ukraińskie.

Zastanawialiśmy się, dlaczego kolekcja Łukowskiego jest taka stonowana, brakuje w niej scen walki, trupów, okrucieństwa, o którym mówią inne materiały źródłowe (Jaczyńska 2012; Kuwałek 2010). Zdjęcia Łukowskiego okresu okupacji w dużej mierze przedstawiają sielskie, wiejskie życie mieszkańców. Zaczęliśmy zastanawiać się, z czego wynika ta rozbieżność? Czy rzeczywiście wsie, po których chodził Łukowski, ominęły wysiedlenia, niemieckie pacyfikacje, Holokaust, ukraińskie rzezie? A może Łukowski specjalnie nie fotografował tych wydarzeń? Wykonanie ujęcia w dużej mierze zależy od intencji i wyboru fotografa, jego stanu świadomości, ale i konwencji wykonywania zdjęcia (Bartuszek 2012). A może problem polega na tym, aby umiejętnie spojrzeć i zinterpretować te fotografie? Chcieliśmy również ustalić, czy obrazy ze zdjęć korespondują ze wspomnieniami zapisanymi w pamięci mieszkańców tych okolic, w tym osób przedstawionych na fotografiach?

\section{SOCJOLOGICZNA ANALIZA ZDJĘCIA}

Kolekcja Łukowskiego składa się z 1500 zdjęć, dlatego z definicji zakładaliśmy, że analizie poddamy jedynie ich część, a do opisu zastosujemy analizę warstwową fotografii. Zakłada ona ewaluację danych fotograficznych, na każdym etapie badania, dokonywaną przede wszystkim poprzez uwzględnienie innych danych zastanych, takich jak dokumenty i inne źródła pisane (np. pamiętniki). George W. Dowdall i Janet Golden (1989), którzy jako pierwsi zastosowali tę metodę do analizy fotografii przedstawiających pacjentów szpitala psychiatrycznego, zwracają uwagę na konieczność przeprowadzenia analizy warstwowej na trzech poziomach: oszacowania, dociekania i interpretacji. W naszym badaniu również zastosowaliśmy taką trójpoziomową analizę, choć poddaliśmy ją pewnym modyfikacjom $z$ racji specyfiki analizowanej kolekcji.

Początkowo staraliśmy się przyjrzeć zdjęciom Feliksa Łukowskiego w ich historycznym kontekście i zwrócić uwagę na niespójności między fotografiami a istniejącymi źródłami pisanymi. W tym celu w czerwcu 2015 roku odbyła się kwerenda archiwalna w Muzeum w Zamościu, gdzie jest przechowywana kolekcja zdjęć Feliksa Łukowskiego. Ten pierwszy etap badania pokazał, że istnieje ogromna niespójność pomiędzy widokami zapisanymi na negatywach Łukowskiego a danymi płynącymi ze źródeł pisanych. Źródeł nie ma wiele, a same Siemnice są traktowane raczej zbiorczo jako jedno z miejsc Zamojszczyzny doświadczających terroru okupacji niemieckiej, jednak $z$ dostępnych informacji 
pisanych wyłaniał się odmienny obraz realiów życia aniżeli ten uwieczniony na zdjęciach. Zygmunt Klukowski (1947, s. 57) pisał na przykład, że w lipcu 1943 roku wysiedlono osiem gromad wchodzących w skład gminy Rachanie: Grodysławice kol., Józefówkę, Michalów wieś, Michalów kol., Rachanie, Siemnice, Wolę Gródecką wieś, Wolę Gródecką kol. Na spakowanie dobytku ludzie mieli około 25 minut. Łącznie wysiedlono ponad trzy tysiące osób, z czego część do obozu w Zamościu, resztę pozostawiono jako robotników u Niemców z Rosji, Rumunii, Łotwy oraz volksdeutschów.

Z kolei Jerzy Markiewicz (1967, s. 35, 37) wspomina pacyfikacje, jakie przeprowadzano w okolicy: 10-13 stycznia $1943 \mathrm{r}$. miała miejsce masakra w Rachaniach, w której zginęło około 100 osób; 26 maja 1943 r. w Rachaniach żandarmi z miejscowego posterunku rozstrzelali 31 osób aresztowanych we wsi Pawłówka, Rachanie i Siemnice, wcześniej bo 31 stycznia 1943 r. miała miejsce pacyfikacja w Siemnicach, w której zginęło 10 osób. Na zdjęciach Łukowskiego można zobaczyć jedynie ekshumację i konwój pogrzebowy z trumnami osób zamordowanych w Siemnicach. Ekshumacja miała miejsce kilkanaście tygodni po pacyfikacji. O pozostałych wydarzeniach zdjęcia Łukowskiego milczą, nie licząc zdjęcia małego Aleksandra Jamróża, który ocalał z masakry w Dzierążni i którego Łukowski uchwycił na rękach siostry Christiany w Tomaszowie Lubelskim.

Te braki przedstawień sprawiły, że postanowiliśmy wyróżnić wzorce i kody mające wpływ na widoki przedstawione na fotografiach. W tym celu pomocne jest - jak proponowali George W. Dowdall i Janet Golden - ułożenie kolekcji w porządku chronologicznym i zwrócenie uwagi na główne zmiany, jakie zaszły $\mathrm{w}$ sposobie prezentacji miejsca, ludzi, o których można wywnioskować na podstawie fotografii i które mogą mieć istotny wpływ na zrozumienie przedstawionego widoku. $\mathrm{Na}$ tym etapie analizy interesowało nas określenie wykorzystanych przez Łukowskiego wzorców przedstawienia poszczególnych tematów. Co ulega zmianie w przedstawieniach osób, wesel, pogrzebów z czasu okupacji w porównaniu z okresem wcześniejszym. Nie było to zadanie łatwe, gdyż jak już była mowa, ułożenie zdjęć w porządku chronologicznym nie jest możliwe; wiele zdjęć nie zostało opisanych i nie jest już możliwa ich identyfikacja. Same obrazy zaś są zbyt podobne, by można było jednoznacznie określić, w którym momencie okresu okupacji zostały wykonane. Na tym etapie natrafiliśmy na klasyczny problem, o jakim piszą badacze materiałów wizualnych: „Fotografia bez kontekstu, opisu jest dość trudna do identyfikacji i opowiedzenia. W pewnym sensie jest niema i jej interpretacja opiera się często na subiektywnym postrzeganiu oglądającego" (Bartuszek 2012, s. 236). To jednak również jest obarczone błędem, gdyż poprawne odczytanie obrazu zależy od wielu zmiennych, takich jak właśnie podpis, ale również kod czy kontekst (Gombrich 1990).

Zmiana widoczna na pierwszy rzut oka dotyczy stroju, przede wszystkim $\mathrm{w}$ przypadku prezentacji chłopców, zarówno stojących $\mathrm{w}$ parach, jak i zdjęć 
grupowych, gdyż w okresie okupacji elementem ich ubioru stają się czapeczki imitujące czapki wojskowe oraz patyki imitujące broń. Obraz chłopców jest zatem dużo bardziej zmilitaryzowany aniżeli w podobnych ujęciach robionych przed wojną. Również stroje pozostałych osób często mają elementy ubioru wojskowego, jak czapka czy płaszcz. Pojawia się nowa grupa osób: Niemców, tzw. nasiedleńców z Besarabii, volksdeutschów, którzy jednak są fotografowani w podobny sposób jak Polacy (będzie o tym mowa dalej). Zmianie ulega również wygląd wsi, szkoła zamieniona na posterunek policji czy dom Jędrusyny w Kolonii Michalów zamieniony na posterunek „granatowej” policji. Trzeba jednak podkreślić, że patrzący domyślają się jedynie tych zmian i wnioskują je $z$ opisów archiwalnych, na zdjęciach nie ma bowiem prawie żadnych atrybutów nowej władzy, swastyk, napisów czy flag niemieckiej Rzeszy. Jedynie tabliczka $z$ napisem „Polnischer Polizeiposten RACHANIE Polski Posterunek Policji" przed szkołą w Rachaniach ${ }^{3}$.

$\mathrm{Na}$ trzecim etapie zakładaliśmy szczegółowe badanie wybranych zdjęć, aby pojąć niuanse i szczegóły wiejskiego życia oraz doświadczeń niemieckiej okupacji. W lipcu

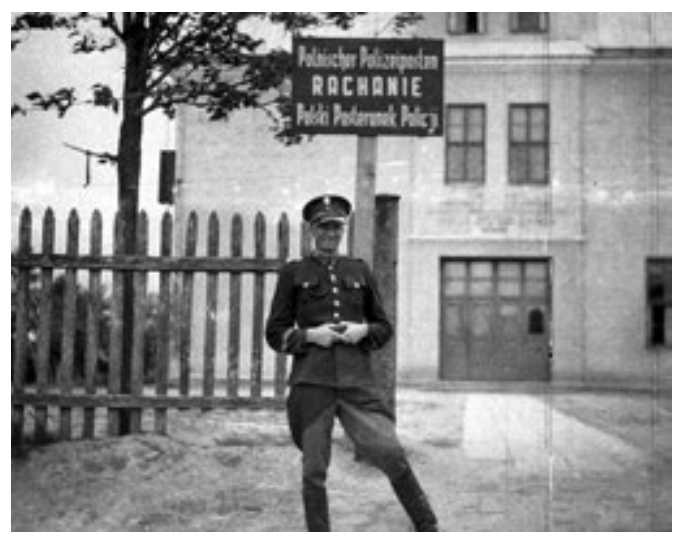
2015 roku wspólnie z badaczami z Archiwum Historii Mówionej DSH przeprowadziliśmy badania w Siemnicach i okolicznych miejscowościach (zob. spis wywiadów). W celu wywołania wspomnień posłużyliśmy się albumem zdjęć Feliksa Łukowskiego wydanym w 2005 roku przez Muzeum w Zamościu, zatytułowanym Świat chałup, stodót $i$ opłotków. Wieś w obiektywie Feliksa Łukowskiego z Siemnic, pow. Tomaszów Lubelski. Fotografie z lat 40. i 50. XX wieku. Album zawiera wybór 382 zdjęć, zrobionych w latach 1942-1950. Większość zdjęć dokumentujących życie pod niemiecką okupacją została umieszczona w podrozdziale „Wojna”. Znajduje się tam 38 fotografii, z czego jedenaście przedstawia pozujących żołnierzy sowieckich. W całej kolekcji Łukowskiego znajduje się kilkadziesiąt zdjęć dokumentujących niemiecką okupację, nie licząc wykonanych w latach wojennych portretów i zdjęć okolicznościowych. Nas interesowały jednak przede wszystkim te, które przedstawiały sceny z życia okresu okupacji. Decyzja o użyciu albumu jako narzędzia wywołującego wspomnienia miała ważne uzasadnienie metodologiczne. Mieszkańcy Siemnic i okolicznych miejscowości znają bowiem ten album i dla wielu z nich ma on wartość pamiątki rodzinnej, tym cenniejszej, że zdję-

${ }^{3}$ Serdecznie dziękuję Dyrektorowi Muzeum Zamojskiego w Zamościu za wyrażenie zgody na publikację zdjęć, które są własnością muzeum. 
cia przedstawiają sceny $z$ ich życia lub ich rodziny, wesela, procesje, prace, pogrzeby. Uznaliśmy zatem, że wszystkie fotografie, nawet jeśli nie przedstawiają wojny, mogą stać się impulsem do wywołania wspomnień z tego okresu.

W trakcie badań dawaliśmy rozmówcy album, aby go obejrzał, zidentyfikował przedstawione na zdjęciach osoby, opowiedział o swoich i ich wojennych losach. Jednocześnie zadawaliśmy pytania związane $z$ okresem niemieckiej okupacji. Chodziło nam o uchwycenie tych wymiarów przeszłości, do których trudno jest dotrzeć za pomocą innych metod badawczych (Geffroy 1990, s. 374; cyt. za: Banks 2009, s. 118). Mieliśmy nadzieję, że dzięki zdjęciom i emocjom, które one wywołają, uda się nam w sposób bardziej empatyczny zrozumieć realia okupacyjnego życia Siemnic i okolicznych miejscowości. Bardzo szybko okazało się jednak, że nie jest to zadanie łatwe, gdyż chłodne

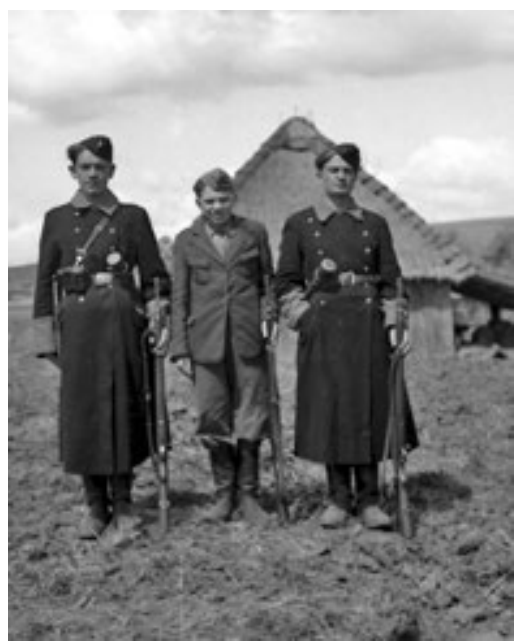
w swym przekazie zdjęcia wywoływały chłodne i zdawkowe wspomnienia, jak to wywołane zdjęciem przedstawiającym trzech młodych mężczyzn. Patrząc na to zdjęcie jeden $z$ rozmówców wspominał: $A$ tych dwóch [to bracia z Uchań - Z.B.] [...], brat $i$ Wicek Kowalczuk, oni z Uchań byli, przyjęli poddaństwo niemieckie $i$ folksliste podpisali $i$ byli nasiedleni. Ale takie historyczne rzeczy [...] [10M]. Nie opowiedział dalej ani czym się zajmowali bracia $z$ Uchań w czasie wojny, ani jaki był ich stosunek do sąsiadów po tym jak przyjęli poddaństwo niemieckie. Zdjęcie wywołało jednak wspomnienia związane $\mathrm{z}$ powojennymi losami Wicka Kowalczuka:

Ja byt na takim rolniczym kursie [...] Na sasiedniej sali... to już byto dawno, to za socjalizmu, ja jeszcze energii miat tyle. Niewiasta, kobieta ładna jedna byta. My chodzili do nich na randki. I ja się z nia dogadał $z$ tą dziewczyna, skąd ona pochodzi. Ona mówi, że ona $z$ Uchań pochodzi. A ja mówię „Czy Pani zna Wicka Kowalczuka?”. A ona mówi „Tożto mój maż”. A ja jej na to „A wie Pani, czym on bet, kim bet?”. Nie wiedziała, ja jej dopiero powiedziat panie. A on byt nasiedlonym, przyją poddaństwo, a oni dopiero byli rok $w$ matżenstwie, nie wiem, co tam wyszto. Ale taka tadna kobieta, że ona poszła za niego! On byt taki ciamajda. A jego tojciec $z$ katarenka po odpustach chodzit [10M].

To wspomnienie wywołane zdjęciem Wicka Kowalczuka z bratem, stojących koło Lońki Steinmüllera z rodziny niemieckich nasiedleńców z Besarabii, pokazuje, że rozmówca ma wykrystalizowaną opinię na temat postawy Wicka, nie ujawnia się ona jednak wprost $\mathrm{w}$ ocenie jego wojennych poczynań, ale poprzez osadzenie jej w systemie wartości społeczności wiejskiej, dla której relacje pokrewieństwa są najważniejszym punktem referencyjnym. Jak pisał Józef Burszta (1976, s. 443), „znaczenie jednostki w tradycyjnej społeczno- 
ści wiejskiej wyznaczone było na ogół nie cechami i walorami osobistymi, ale pozycją społeczną jej rodziny", dlatego rozmówca w celu deprecjacji Wicka Kowalczuka przywołuje fakt, że jego ojciec był kataryniarzem, a więc parał się nisko społecznie cenioną profesją.

Wśród zdjęć Łukowskiego mało jest widoków wojny, podobnych do tych znanych z fotografii dokumentalnych. Zdjęcia uśmiechniętych Niemców czy pozujących partyzantów nie są typowymi wojennymi fotografiami, dlatego aby je zrozumieć, pytaliśmy rozmówców, jak pamiętają okupację. Odpowiedzi były jednak bardzo zdawkowe: Lepiej nie pamiętać i nie mówić [1M] czy Wszędzie nieszczęście byto. Aby nie dać się Niemcowi złapać. Aby nie dać się Niemcowi złapać. [...]. Ciężko byto [11K]. Dopiero szczegółowe pytania lub konkretne fotografie stawały się pretekstem do opowieści. Interesujące jest jednak to, że $\mathrm{w}$ przeciwieństwie do pytań, na które rozmówcy odpowiadali chętnie i na temat, fotografie były impulsem do różnego rodzaju wspomnień, czasem odbiegających od tego, co jest przedstawione na fotografii. Ciekawym przykładem jest jedyny znajdujący się w kolekcji Łukowskiego cykl zdjęć przypominający sekwencję reporterską i dokumentujący ekshumację dziesięciu ofiar pacyfikacji, która miała miejsce 31 stycznia $1943 \mathrm{r}$. w Siemnicach.

W większości zdjęcia te przypominają fotografie wykonane przez autora na innych pogrzebach. Łukowski uwiecznił konwój żałobny idący na teren cmentarza w Wożuczynie oraz grupę wszystkich uczestników pogrzebu, pozujących do zdjęcia $z$ trumnami stojącymi przed nimi. Zdjęcia te są bardzo spokojne i zachowane w stylistyce zdjęć pogrzebowych. W cyklu znalazło się jednak kilka fotografii wymykających się tej stylistyce i ujawniających dramatyzm sytuacji. Przykładem jest zdjęcie przedstawiające odkopywanie i wydobywanie z ziemi częściowo już rozłożonych ciał i umieszczanie ich w trumnach. Łukowski uwiecznił tłum przypatrujący się całemu zajściu. Ludzie nie są świadomi obecności fotografa, Łukowski fotografuje ich jakby $z$ ukrycia. Wyjątkowe dla kolekcji Łukowskiego są również zdjęcia przedstawiające składa-

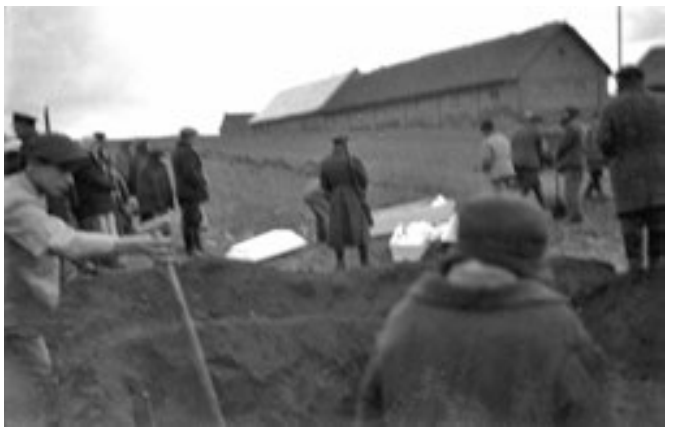
nie trumien w grobie na cmentarzu. Wszystkie te zdjęcia są źle skadrowane, w przeciwieństwie do innych fotografii autora, są nieostre i częściowo zaciemnione. Widać, że były zrobione w pośpiechu. Ujawniają one emocje fotografa, który nie skupiał się na samej fotografii, ale chciał udokumentować ważne dla grupy wydarzenie historyczne, jakby mimo wszystko, mimo własnej nieumiejętności bycia reporterem.

Jednak ekshumacja i pogrzeb ofiar uwiecznione na fotografiach Łukowskiego nie wywoływały wśród rozmówców wspomnień tamtego wydarzenia 
i emocji z nim związanych, ale stały się impulsem do opowiedzenia historii, która doprowadziła do śmierci ofiar, samego mordu, ale przede wszystkim tego, co w tym czasie działo się z opowiadającym. Jedynymi wspomnieniami bezpośrednio nawiązującymi do obrazów na zdjęciach były wypowiedzi starszego małżeństwa, które wskazało konkretne miejsce pochówku ofiar: Tutaj, jak tu moja obora $z$ tytu, byto dziesięciu pochowanych [9K], mąż z kolei dodawał A wszystkie byli pochowane to tu, gdzie ten kombajn stoi. Tu byta jama wykopana, później żeśmy ich wykopali [10M]. Obydwie wypowiedzi pokazują, że również w tym wypadku punktem referencyjnym jest sam rozmówca, jego obora, kombajn. Mężczyzna wspomniał również, kiedy miało miejsce wydarzenie: Ale to ekshumacja to już na wiosne byto, pozwolenie ten soltys przynióst z gminy przynióst, że można zakopać [10M]. Jak widać, wypowiedź jest bardzo krótka i ogólna.

Mieszkańcy wsi nie wspominali, jak doszło do wydania zgody, kto ekshumował, jakie były reakcje rodzin i bliskich zamordowanych na widok ciał. Szczegółowo opowiadali za to o samej pacyfikacji. Jak wspominał cytowany już rozmówca:

[...] to byto prosze pana dwa folwarki w Siemnicach na polu. I w jednym folwarku tucznik w nocy, partyzantka wzięta. No i Niemcy zameldowali, bo to świnie byli kolczykowane i musiat się pan rozliczyć i pytaja się tej stużby, kto mógł ukraść te świnie? Oni mówia, że „my nie wiemy, to partyzantka”. Ślady, ślady w którym kierunku? W strone Siemnic. No $i$ duże buty, kto ma w Siemnicach takie duże buty? Tu mieszkat Pawet. [...] No i Niemcy przyjechali, a mieli ich notowane, jako podejrzane i mówili ,jeszcze raz jak się powtórzy, to śmierć". No i powtórzyto się $w$ drugim folwarku, ale oni nic nie byli winni. Nie wiem, czy to partyzantka, czy to partyzantów byto, czy ztodziei. I to byta niedziela, 31 styczeń 1943 rok. Tak, przyjechali, ja sam wyszed, [...] Panie, jak Niemcy tylko pobili tych, to ja od razu ze schowku wyszedt $i$ od razu do sasiada poleciat tam. Patrze, a oni z pocisków rozstrzelali takich rozrywających. Jak pan strzelit w tutaj czoło, $z$ tytu można byto pięść potożý, tak rozrywato. $O$, to otworzyt drzwi, a to taka chatupka byta, jak tu mamy. No to ta babcia byta pod tóżkiem widać $z$ bólu, a dziewczyna Janka, taka z mojego roku to się klęczała i trzymała książeczkę, widać się modlita, bo to byta niedziela $i$ druga rękę za tę, widać jak się modlita tak ją zabili, a druga ręka za poręcz tóżka [10M].

Zanim jednak opowiedział, co widział, detalicznie opisał, co się z nim działo: Niemcy weszli i rozstrzelili [...], a ja zobaczyt i raz dwa do domu, [...] a na strychu byt schowek, jak dach idzie tak, o, ukośnie, to my jeszcze zrobili proste i my tam pouciekali. $J a$, bracia $i$ tato $[\ldots]$. $Z$ kolei inny rozmówca tak wspominał to wydarzenie:

My z tym kolega tutaj o tędy, pani, z tej burty [pokazuje] lecieliśmy uciekać na te stawy, to $i$ do lasu tędy. A tu u mnie na ogrodzie, tam z tytu, Niemiec $z$ maszynowym karabinem. Jużeśmy byli okrążone. I tylko my wylecieli tak o na te tąki z tego zakrętu, ten nas jak zauważyt i po nas maszynowym karabinem! I tak: śnieg przed nami i za nami. To my padamy, ale jak cała wieś, jest na świecie siła boża, coś takiego przyszło do głowy żeby nie uciekać dalej, tylko żeby się wrócić $z$ powrotem do wsi. [...] $i$ myśmy się wrócili $z$ powrotem. Tu na dole byto, stali takie chlewki takie, chlewy takie, jak to kiedyś byto. Myśmy się schowali do tych, do tych chlewków proszę pani, byto nas, jeszcze taki starszy gość przyleciat, on miat astmę i zacząt kaszleć. Ja se myślę: jak on zacząt kaszleć, jak 
Niemcy postysza, to przyjdą. A mój kolega miat karabin i mówi: żywi się nie damy. Stanąt $w$ drzwiach $z$ karabinem, tragedia! Ja se myślę: co to będzie? To ja w, panie, wymknątem sie $i$ tu o, przez tego, tu taka obora u mnie stała, tutaj gdzie teraz ten dom stoi, ja do tej obory i na górki. A na górce byto troche czystego, koniczyny takiej. [...] No. już leże jakieś $z$ pót godziny cichutko, stucham płacz już w Siemnicach. Już ludzie płacza, sie zlatali $[2 \mathrm{M}]$.

W dalszej części wywiadu wspominał widok zamordowanych ciał sąsiadów. Z kolei kobieta, która wówczas miała pięć lat, wspominała widok pomordowanych ludzi:

Mama mnie wzięła za rękę i prowadziła mnie, jako dziecko. To leżat ojciec, taki młody, ja wiem, ile miat lat, żona $w$ ciąży leżała, tak, na ten, a dzieciunio na ziemi, bo wtedy podłogi nie było, a dzieciunio na tóżku $z$ pierogiem $w$ ręce. To ja to widziała, dalej wspominała, To pamiętam. To ja byta jako dziecko. [...] A już tam dalej po domach to te $\dot{z}$, koło drogi stat dom $i$ byta zabita matka $z$ córka $i$ dalej tam, trzy ogrody dalej byty zabite dwie dziewczyny, jedna $z$ mojego wieku i babcia. Tak byto. To ja już nie chodzita. Tam mnie już nie prowadzili [9K].

Warto zaznaczyć, że wspomnienia pacyfikacji wywoływały również inne zdjęcia znajdujące się $\mathrm{w}$ albumie, jak to umieszczone $\mathrm{w}$ podrozdziale „Razem”, a przedstawiające „Michała Łukasika z córką Stasią stojącą na taborecie i kuzynką Stefanią Parol". Natrafiwszy na tę fotografię, przywoływany już rozmówca wspominał, pokazując na drugi pokój swojej chałupy: Ta dziewczynka, ta to, to Stasia Eukasiuk, to ona zabita tu o, tam gdzie w moim pokoju, tam mój stót stoi $w$ tym miejscu. Niemcy ja zastrzelili [10M].

Przytoczone fragmenty wywiadów pokazują, że świadkowie wydarzeń pamiętają przede wszystkim te wydarzenia, w których sami brali udział i które dotyczą ich losu. Nie oznacza to jednak, że każde wydarzenie zostaje zapamiętane. Fakt, że rozmówcy tak detalicznie przytaczają samo zajście, pokazuje, że pacyfikacja stanowiła zagrożenie dla życia rozmówcy i dlatego została tak detalicznie zapamiętana (por. Łuczewski 2012, s. 365-366). Rozmówcy niewiele jednak umieli opowiedzieć o innych pacyfikacjach, jakie miały miejsce w sąsiednich miejscowościach, co może być odczytane jako przejaw zjawiska selekcji, silnie determinującej chłopską pamięć. W kulturze chłopskiej zapomnieniu podlegają wszystkie informacje nieistotne z punktu widzenia grupy, a zapamiętaniu, jak tłumaczy Ryszard Tomicki (1981, s. 359): „niemal wyłącznie wydarzenia mające miejsce w najbliższej okolicy. Powodowało to, że historyczne doświadczenia społeczności lokalnych miały — by tak rzec — ograniczoną skalę, na której zawężenie wpływał ponadto partykularyzm poznawczy społeczności chłopskich, wyrażający się w stosowaniu lokalnocentrycznej miary dla oceny wagi i znaczenia wszelkich wydarzeń". Ten lokalnocentryzm jest bardzo widoczny we wspomnieniach rozmówców.

Zdjęcia Łukowskiego są zatem nośnikiem wspomnień o wydarzeniach innych niż te, które zapisały się w pamięci rozmówców. $Z$ kolei wspomnienia rozmówców pokazują, jak bardzo wybiórcze są widoki Łukowskiego, co wywołuje 
pytanie, dlaczego Łukowski nie sfotografował tych wydarzeń. Z wypowiedzi rozmówców można wywnioskować, że po pacyfikacji ludzie zeszli się obejrzeć ofiary, nawet pięcioletnią córkę [9K] matka przyprowadziła, co pokazuje, że praktyka oglądania miejsca zbrodni była powszechna. Dlaczego zatem Łukowski nie uwiecznił tych czy innych widoków pacyfikacji? Nie wydaje się, by powodem był strach, biorąc pod uwagę fakt, że z łatwością fotografował swoich przyjaciół partyzantów z bronią, o czym będzie dalej mowa. O tym, jak mało kolekcja Łukowskiego mówi o okupacyjnej rzeczywistości i doświadczeniach osób przedstawionych na zdjęciach, świadczy przede wszystkim nieobecność na zdjęciach tego, co najmocniej zapisało się w pamięci rozmówców, czyli zagłady Żydów i mordów ukraińskich na Polakach na Wschodzie.

\section{ZAPAMIĘTANE - NIE UWIECZNIONE: O NIESFOTOGRAFOWANYCH WYDARZENIACH}

W albumie znalazły się tylko dwie fotografie przedstawiające Żydów, jednak nie zostały one wykonane przez Łukowskiego, lecz przez jego przyjaciela Lewczyńskiego i omyłkowo włączone do kolekcji fotografa z Siemnic. Ten brak Żydów w kolekcji Łukowskiego wydaje się znaczący, gdyż mimo że rodzin żydowskich nie było przed wojną w Siemnicach zbyt wiele, to jednak pamięć o żydowskich sąsiadach i ich zagładzie jest bardzo żywa wśród mieszkańców tych okolic, co pokazuje, że Polacy i Żydzi żyli w dobrych stosunkach i współpracowali. Co prawda, na pytanie, jak się żyło z Żydami przed wojną, świadek tamtych czasów wspominał: To nie było nic takiego złego, jak to mówili: „Jak bida, to do Żyda, jak po bidzie - pocałuj mnie Żydzie”. No i tak byto. $\dot{Z} y d$ to byt obcy, nie byt tutejszy. Byt obcy. Przyjaźni specjalnej nie byto. Ale byto, że u Żyda można byto się zaratować. On miat swoje zdanie, on pożyczał przypuśćmy jakaśs część, tyle zaptacisz jemu i tyle. $Z$ tego się utrzymywat [3M]. Jednak większość osób opowiadała o wzajemnych dobrych kontaktach. Jedna $z$ kobiet wspominała: To ja pamiętam, $\dot{z}$ j ja chodzita im, to mi dawali pare groszy $w$ sobote oni nie podpalili ognia [...]. To ja im podpalałam, rozpalatam, herbate zagotowałam, tak to mi dali pare groszy za to. Dalej mówiła: Kiedyś, o, jabtek nie ma komu, jak to mówia, leca i marnuja się i tego, a oni takie Żydy [...] wynajmowali ten sad $i$ tam już siedzieli całe lato, $i$ tam do nich się chodziło jabtka kupować [2K]. Pamiętano żydowskie sklepy, jednak na zdjęciach Łukowskiego nie ma ich, ani żadnych atrybutów świadczących o obecności żydowskich sąsiadów. Oglądając zdjęcia odnosi się wrażenie, jakby wieś była etnicznie polska, jakby nie było tam żadnych Żydów.

Rozmówcy bardzo dokładnie wspominają samą Zagładę swoich sąsiadów:

Niemcy dali zarzadzenie, że do godziny dziesiatej wszyscy Żydzi [w Siemnicach] maja się zejść [...] u Holtzera. O. I oni o, sottys im nakazat, niektórzy uciekli, a innych tam przepędzili, tam złapali. A ta Hajka szła, ja mówię żebyśs nie szła Hajka. Panna, już miała dwadzieścia trzy lat. „Bo Niemcy będa rozstrzelać Was wszystkich, oni Was po to wotali”. „A, co będzie wszystkim to i mnie”. I poszta i rozstrzelili wszystkich [10M]. 


\section{A oto inne wspomnienie tego samego zajścia:}

I myśmy tam naprzeciw naszego warsztatu, tam dokonywali tej zbrodni, ja widziałem. Mówie pani, że jak pan Bóg broni, strzelali z rozlewnych tych pocisków, aż wtosy fruwali. Pięć żandarmów. Kazali im się tak potożyć, uklęknać, a tu dót już byt wykopany i z maszynowego karabinu. Pierw po dzieciach, a dzieci takie małe, $z$ dziesięcioro dzieci byto, starcy, dziadkowie... [2M].

Obydwie wypowiedzi pokazują, że pamięć o Zagładzie jest szczegółowa, wiąże się z konkretnymi osobami - sąsiadami, których rozmówcy znali i których śmierci żałują: Fajne Żydy byli! Czego to tak mordowali te Niemcy? [2K]. Pamięć o Zagładzie nie jest zatem zwykłą pamięcią o wydarzeniu: „to było”, ale pamięcią refleksyjną, pokazującą, że ludzie zastanawiali się nad tym, co się dzieje i dlaczego się to dzieje i nie umieli sobie na to pytanie odpowiedzieć. O tym, że sąsiedzi i ich zagłada nie była im obojętna, świadczy fakt, że rozmówcy mają bardzo dokładny obraz tamtych zajść, pamiętają śmierć osób, które znali. Jak opowiadała mieszkanka Wożuczyna o zagładzie w jej wsi:

Oni uciekali. To na szosie jeden uciekat, to Boruch go nazywali, to go zabili. Trzy dziewczynki, jego córki, w oborze znaleźli, pod krową. Krowa się spalita i... Bo to oni myśleli jak spala, no nie wiem, podpalili swój dom te Żydzi. A tego Fisicha to nie pamiętam co $z$ nim, chyba też zabili, pamiętam Zunga córkę, uciekata do Dziaduchów, tam do sąsiadów, już byta na progu i zabili ją na progu, pamiętam bardzo dobrze. Już nie pamiętam jej imię... Rywka chyba miała, tak. No. [...] Ten Zung miat dwoje dzieci, Rywkę i chtopca. [...] Rywkę to pamiętam lepiej, takie miała tadne dlugie wtosy. I zara ich tu zakopali wszystkich $w$ jeden dót, tych naszych $z$ Wożuczyna. To niedaleko nas byto przecież [4K].

Młoda Rywka była osobą powszechnie znaną i podziwianą za swoją urodę:

Rywka się nazywała, chodzita ze mna do szkoty razem. [...] Taka byta fajna ta dziewczyneczka, wtosy jakie miała ładne, warkocze takie mmm! Jak lalka. [...] Ktoś tu mówit, $\dot{z}$ e ona tak się prosita, ta Rywka, tak się prosita, coś do nich mówiła po niemiecku, że tak tam gdzieś, kto tam gdzieś byt w pobliżu tak opowiadat. Nie byto uproś, tchnat $i$ już, zabit $[2 \mathrm{~K}]$.

Zdjęcia Łukowskiego nie opowiadają całej tej historii, nie ma na nich również pięknej Rywki, mimo że fotograf lubił fotografować młode, piękne kobiety.

Wiele osób w sposób bardzo podobny wspominało to, co się wydarzyło w ich okolicy, co świadczy o tym, że ludzie rozmawiali o zagładzie sąsiadów, nikt jednak $z$ naszych rozmówców im nie pomagał:

Nie mieli warunków Polak, żeby chciat. Nie jeden $z$ politowaniem o nich sie odzywat $i$ jak najbardziej szkoda, bo gdzież to tak można? No ale przytrzymać panie, to grozito wybiciem całej rodziny. A gdzie ich trzymać, żeby sasiad się nie dowiedział? A sąsiad język ma. Poniesie do drugiego, drugi poleci tam. [...] Swoich, sasiad sasiada się bat. Bo sasiad może niespecjalnie, może nieświadomie wygadatby do drugiego, a drugi do trzeciego i tak się doniesie tam, gdzie nie trza $[3 \mathrm{M}]$.

Rozmówcy wspominali Żydów, którym udało się uniknąć śmierci, co pokazuje, że również po wojnie rozmawiali o ich losie: Tu gdzieś na Kolonii Mi- 
chalowskiej Pieprzowski ukryt Żyda. Wyjszedt tam po wyzwoleniu, bidny byt, modziak taki, on bidny byt, no ale przeżyt [3M]. Inni wspominali Żyda, który wyjechał do Rosji, młodą Zydówkę, która ukryła się i przeżyła na robotach w Niemczech. Rozmówcy jednak nie znali tych osób bezpośrednio, nie umieli wymienić ich imion, co tłumaczy, dlaczego wszyscy jednogłośnie na pytanie, czy ktoś z Żydów przeżył, odpowiadali, że nie - nikt z ich sąsiadów, których znali i lubili, nie przeżył Zagłady.

Interesujące jest, że fragmentem pamięci o Zagładzie Żydów jest wojenna historia przedwojennych właścicieli folwarku w Siemnicach, Holtzerów. W kolekcji Łukowskiego znajduje się jedna fotografia rodziny Holtzerów, zrobiona przed domem w majątku Siemnice. Jednak zdjęcie to nie wywoływało żadnych wspomnień o byłych właścicielach majątku i pracodawcach. Wypowiedzi były bardzo zdawkowe, że byli, że byli dobrzy. Jedyne narracyjne wypowiedzi pojawiły się, gdy rozmówcy opisywali Zagładę Żydów w Celestynowie i wówczas wspominali Marię i Mieczysława Holtzerów zamordowanych za pomoc Żydom w listopadzie 1942 roku: Ona miata Żydów, oni przyjechali tych Żydów pobić, bo mieli takie zadanie, żeby ich pobić $i$ ona stanęta po ich stronie, $\dot{z} e$ oni pracowity, że jeszcze, jeszcze, no. I wzięli ja $i$ męża $i$ zabili. I $w$ jednej jamie pochowali $[3 \mathrm{M}]$.

Innym problemem nieobecnym na fotografiach Łukowskiego, a żywym we wspomnieniach rozmówców, są ukraińskie rzezie na Polakach. Co prawda, Ukraińcy nie dochodzili do Siemnic, ale - jak wspomina ten sam rozmówca — Już tu za Łaszczowem byto stychać. [...] Tu do nas nie dojszli, tak. Ale najszli święta wielkanocne, to jechali fura za fura. Uciekali stamtą ludzie. Załadowane na wóz [3M]. Z kolei mieszkanka Wożuczyna mówiła: jedna łuna była, cały wschód się palito. I te akcje rozmaite noca, na każda wioskę, każdej wioski paliło się, [niezroz.] byto stychać jęki, pisk byt, prawie stychać tutaj. I jednych $i$ drugich [2K]. Rozmówcy pamiętają tamte wydarzenia bardzo detalicznie:

Ale potem jak gdzieś ja byta tam, nie wiem po co, nie wiem jak, nie wiem po co ja tam byta, tam tylko stali takie kopce, popalone domy, tak Ukraincy bili, nawet na ptot nadziewali, na sztachete tak, $i$ dzieci, $i$ kobiety. A jeszcze tam jeden opowiadat jak jedna kobieta, ta kobieta pisała o sobie, może $w$ gazecie, $w$ tygodniku byto, urodzita dziecko $i$ nie mogła uciekać $i$ wystali do tego domu, żeby ja zabili. A jedne tam staly na straży na dworze, a jeden przeszedt zabić, mówi ona już prawie nie żywa byta jak on wszedt, a dziecku wsadzita do buzi pierś, żeby nie zaptakato, a on tak wszedt, podeszedt do tóźka, zagladną $i$ wychodzi na dwór: Nie ma nikogo — powiedział — odejdźmy stąd. No $i$ jednak jedna ganita, a druga chwalita, że ja nie zabili i tego dziecka. [...] A to $w$ Wożuczynie dużo byto tych wysiedleńców, uciekinierów z Ukrainy, Boże, wszędzie, i we dworze, to podworskie te domy i w tamtym domu [...]. Wszystko uciekało od śmierci, ale potem się ucichto, ucichto, wrócili na swoje i już [4K].

Zdjęcia Łukowskiego milczą o wszystkich tych zajściach. Być może w portretach fotografa znajdują się zdjęcia uciekinierów ze Wschodu, gdyż - jak pisał bowiem Lewczyński (2005) - Łukowski z łatwością nawiązywał kon- 
takty z ludźmi i jego kolekcja zawiera wiele zdjęć osób przypadkowo napotkanych. Jednak wiele portretów nie zostało zidentyfikowanych, postacie pozostają nieme.

\section{PUNCTUM W ZDJĘCIACH ŁUKOWSKIEGO}

Album wypełniony jest nieznanymi bohaterami, dlatego nasi rozmówcy przeglądali zdjęcia, ale w większości nie patrzyli na nie, ich opowieść toczyła się jakby obok albumu. Tylko kilka zdjęć przykuło uwagę i wywołało bardzo żywe wspomnienia. Jedno $\mathrm{z}$ nich to zdjęcie wykonane w Kolonii Michalów przed domem Jędrusyny, który został zamieniony na posterunek granatowej policji. Przedstawia pięciu mężczyzn, w większości policjantów, i jedną kobietę. Czterech mężczyzn patrzy w obiektyw, jeden odbiera małą paczuszkę z rąk śmiejącej się kobiety. Uwagę jednego $z$ rozmówców przykuła jednak postać stojącego trochę $z$ tyłu, na

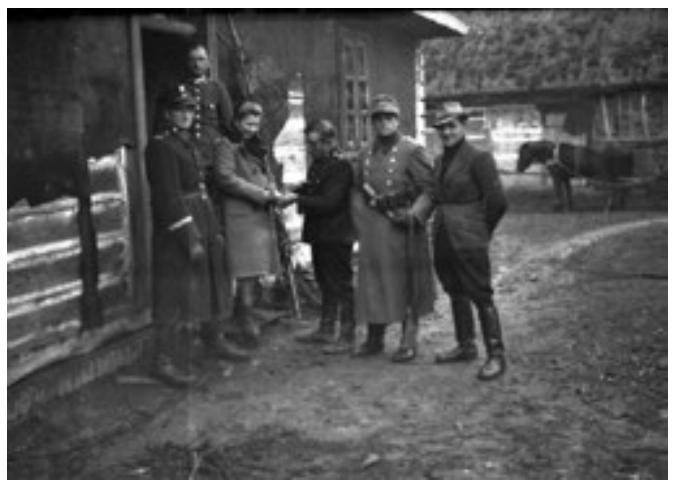
schodach policjanta granatowej policji, komendanta niemieckiej żandarmerii $z$ Tyszowiec, Schultza: on byt komendantem gestapo w Tyszowcach. Komendant gestapo, to tak jak u nas pierwszy sekretarz komitetu PZPR komitetu wojewódzkiego, taki byt ważny. Jak podkreślał dalej: to byt taki Niemiec, że on nie zjadt śniadania [...] Musiat najpierw zastrzelić $\dot{Z} y d a$, dopiero zjadat śniadanie [10M].

Kolejna fotografia przedstawia konwój pogrzebowy niosący dwie trumny, Adolfa i Wawrzyńca Ślebodów. Ojciec Wawrzyniec był powszechnie szanowanym felczerem, jego syn Adolka poszedł na studia medyczne i właśnie przyjechał do Siemnic. Kobieta, która jako młoda dziewczyna była świadkiem tych

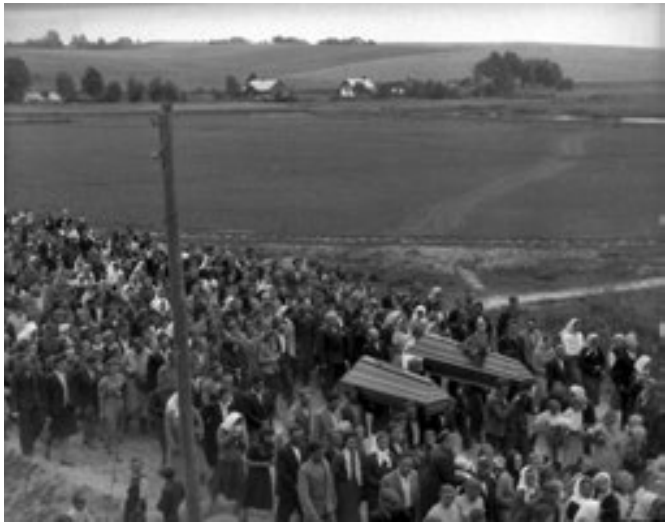
wydarzeń, wspominała:

Tyle pamiętam, że on chyba szedt ze swoim kolega, Zygmuntem Monsielem, szli na akcje [...], zobaczyli nadjeżdżających tych nasiedleńców niemieckich, że jada z bronia, furmanka. Więc oni obaj $w$ zboże chcieli się skryć $i$ skryli się, $z$ tym, że jak się zboże poruszyto, widocznie ci zauważyli i oddali kilka strzałów $i$ akurat tego Ślebodę trafili tak. $A \dot{z} e$ on miat ranę $w$ brzuchu, to niestety nic się nie dało uratować. Zmart. [W żałobie 
po stracie syna ojciec otruł się] zaraz rano. Kwasu solnego się napit, czy siarkowego kwasu. Byt pogrzeb taty i syna. Tragedia [5K].

Ponieważ ojciec i syn byli powszechnie szanowani, na pogrzeb przyszło wiele osób. Ponadto Adolka był partyzantem, dlatego żegnali go koledzy partyzanci oraz mieszkańcy okolicznych wsi. Organizatorem pogrzebu był Łukowski, który znał się z młodym Ślebodą z partyzantki. Rozmówcy wspominają, że pogrzeb był bardzo niebezpieczny: Także to było ryzyko wtedy jak byli Niemcy. Wpadli to byliby ja wiem co by zrobili. Toż to byta żandarmeria w Rachaniu. Takie skupisko, takie zgromadzenie duże [10M]. Inna osoba wspominała, że tragedii prawdopodobnie zapobiegł Karol Hen, który był administratorem majątku w Siemnicach:

A dyrektor Niemiec mieszkat tutaj w Cukrowni, wiedziat o tym pogrzebie i prawdopodobnie, ja tego nie widziałam, ale mówili że wyszedt tutaj, [...] w czasie pogrzebu tego Adolka, bo Adolek byt ttumaczem dyrektora [...]. Ale być może on jeszcze załatwit cała sprawę, że prosze pana żandarmeria, która byta w Rachaniach, nie przyjechali, bo oni tutaj przyjeżdżali, jakoś coś tam załatwit $z$ nimi, żeby oni tutaj nie wtargnęli, bo bytaby tragedia. Bo tylu byto partyzantów, bytaby tragedia $i$ bytoby jakieś starcie niemożliwe $[5 \mathrm{~K}]$.

Wypowiedzi te pokazują, że pogrzeb Ślebodów był rzeczywiście ważnym wydarzeniem w życiu społeczności, większość albo w nim uczestniczyła, moja żona tu niosta wieńce. Wieńce nieśli [pokazuje na zdjęciu] [2M], albo przynajmniej słyszała. Jednak zdjęcia Łukowskiego nie oddają wyjątkowego charakteru tego pogrzebu. Uchwycony kadr, podobnie jak w przypadku konwoju pogrzebowego ekshumowanych ofiar pacyfikacji, niewiele różni się od typowych zdjęć pogrzebowych fotografa $z$ Siemnic.

\section{CHŁOPSKA ALTERNATYWNA HISTORIA OKUPACJI}

W kolekcji Łukowskiego znajduje się kilka nietypowych zdjęć życia pod okupacją niemiecką, które ujawniają jej wymiar często przez historyków tabuizowany. Chodzi o motyw „dobrego Niemca”, który również często pojawia się we wspomnieniach rozmówców. Najlepszym przykładem jest postać Karola Hena, którego wspominało kilku rozmówców w różnych kontekstach. Wielokrotnie już cytowany rozmówca mówił na przykład, że to byt bardzo dobry cztowiek, co jakiś czas jedne krowę rżnat $i$ stużbie rozdawat [...] — dalej wspominał - Ale dobry byt, Kozun z Siemnic panie pojechat do Tomaszowa. Łapanka byta i Niemcy go zabrali na Majdanek go zawieźli. I żona poszła, prosiła $i$ on pojechał z Majdanka przywiózt tego. Przywiózt, panie [10M]. Z sympatią wspominano również innych „dobrych” Niemców. Mieszkaniec Krynic zaś opowiadał, że jeszcze w 1939 roku, wtedy dwa lata miatem, to u nas mieszkali Niemcy $i$ jeden $z$ tych Niemców, tak miat kilkoro dzieci, no to nosit mnie na rękach, uczyt, później ja jakoś tak nie wiem, doszedłem do wniosku skąd ja tyle znam stówek niemieckich [5M]. Z kolei inny mężczyzna wspominał pojawienie się żołnierzy niemieckich w jego wsi: 
Wojsko najechato, dzieci wylecieli, zaczęli ich witać, te rzucali cukierki, starszym papierosy rzucali, przyjaźnie przyjechato wojsko. Byli nie za dtugo i gdzieś udjechali z powrotem. I take scenę małe powiem. Jak udjeżdżali, to jeden $z$ bidnej rodziny witat ich, czy żegnat, ja wim jak to powiedzieć (śmiech). To śmieszne wygladato, te odjeżdżali, a ten machat, bo myślat, że cukierka dostanie. Oni byli w porządku wojsko, a później najszła żandarmeria to paskudnie byto [3M].

Fotograficzną opowieścią o „dobrym Niemcu" jest cykl ośmiu zdjęć, jakie Łukowski wykonał Lilii Steinmüller z rodziny Niemców przesiedlonych z Besarabii. Trzy fotografie przedstawiają młodą Lili ubraną w bikini. Mimo skąpego stroju, dziewczyna nie wydaje się onieśmielona obecnością fotografa, ale swobodnie i z uśmiechem spogląda w obiektyw aparatu. Pozostałe zdjęcia zostały wykonane wiosną i zimą, na wszystkich dziewczyna jest uśmiechnięta, zalotnie spogląda w obiektyw aparatu lub przybiera specjalną pozę do zdjęcia. Nie wydaje się, by Łukowski był zmuszony do wykonania tych fotografii, w jego kolekcji nie ma innych „nasiedleńców”, co pokazuje raczej, że

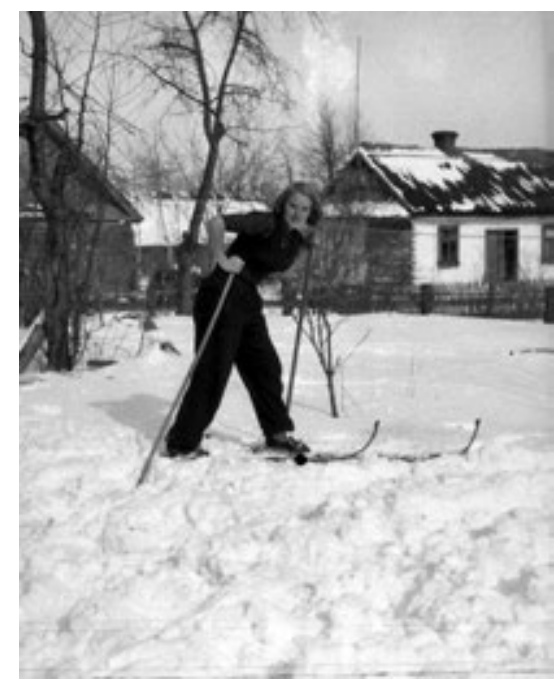
Łukowskiego łączyły prawdziwie przyjacielskie relacje z młodą Niemką. Można to wywnioskować $z$ fotografii przedstawiającej Lili na nartach. Mimo dużej ilości śniegu, Lili ma na sobie krótki rękawek i z uśmiechem pozuje do zdjęć. Nie wydaje się zatem, aby Łukowski zrobił jej zdjęcie przypadkowo, raczej wspólnie bawili się $\mathrm{w}$ śniegu, gdy pojawił się pomysł wykonania fotografii.

Fotografii młodej Niemki trudno byłoby użyć jako ilustracji „,̇ycia pod okupacją niemiecką", opowiadają bowiem historię o okupacyjnej rzeczywistości odmienną niż ta, o której uczą szkolne podręczniki. Zdjęcia młodej Lili i wspomnienia naszych rozmówców pokazują, że relacje polsko-niemieckie w czasie wojny nie przez cały czas i nie ze wszystkimi były napięte i nacechowane strachem. Lewczyński pisał (2005, s. 10): „Te fotografie mogą budzić podejrzenia, jak można było w czasie wojny być beztroskim”. Fotografie pokazują, że można było. Życie toczyło się, a terror, który w opowieściach prowadzonych na poziomie wielkiej historii wydaje się wszechobecny, de facto dramatycznie pojawiał się w momentach przerywających codzienność wypełnioną normalnym życiem, ślubami, procesjami, pogrzebami.

O „beztrosce” życia najlepiej świadczą zdjęcia zrobione przez Łukowskiego kolegom partyzantom - widać ich twarze, posiadaną przez nich broń, miejsca konspiracji, uczestników akcji partyzanckich, głównie wypraw odwetowych na Ukraińców, ale są to również pozowane inscenizacje akcji partyzanckich. $\mathrm{Na}$ kilku zdjęciach możemy zobaczyć partyzantów prowadzonych przez niemiec- 


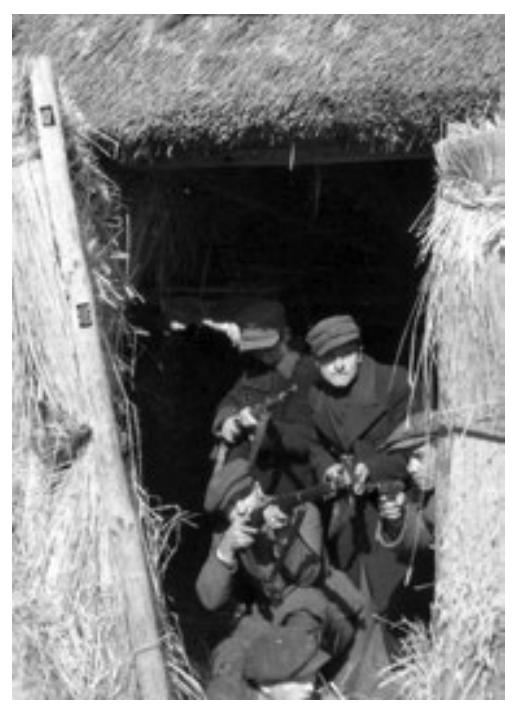

kich żołnierzy, według Adama Kulika to inscenizacje robione wspólnie przez Łukowskiego i niemieckich żołnierzy zatytułowane „łapanie partyzantów" (Kulik 2005, s. 7). Zdjęcia takie nie są pojedyncze, mają wyraźną reprezentację w kolekcji Łukowskiego. Tym bardziej nasuwa się pytanie, jak było to możliwe, skoro znane były takie historie jak ta opowiedziana przez jedną z kobiet:

No tam, gdzie ja później wyjszłam za maż [...]. Ukrywat sie Sowiet $w$ lesie, ale tam gdzieś na kolonii do jakis tam chodzit i pomagali mu, dawali mu źryć, czy czego. No i niby podobała mu sie ta dziewczyna, сzemu by тu się nie podobała? Ale źle, że mu dała swój, swoje zdjęcie. Potem jak te Niemcy go zlapali [...] no to tego, ta dziewczyna to tak samo ja zabili, jak niego. Po tym zdjeсіи $[11 \mathrm{~K}]$.

Mimo śmierci grożącej za działalność konspiracyjną partyzanci chętnie fotografowali się. Jak to jest możliwe? Dlaczego byli tak lekkomyślni? Fotografie Łukowskiego nie odpowiadają na te pytania, jak każda fotografia są niemym zapisem przeszłości. Rzucają jednak nowe światło na życie pod niemiecką okupacją.

\section{UWAGI KOŃCOWE O CHŁOPSKIEJ PAMIĘCI}

Kolekcja zdjęć Łukowskiego nie jest wiernym i wieloaspektowym zapisem życia zamojskich wsi pod niemiecką okupacją, jak chcieliby tego niektórzy badacze. Obrazy ze zdjęć Łukowskiego daleko odbiegają od wspomnień, jakie ludzie mają z okresu okupacji, nie da się zatem za ich pomocą zrekonstruować życia w tamtym okresie. Jednocześnie to właśnie ta wybiórczość i selektywność sprawia, że kolekcja jest tak ciekawa. Wydaje się idealnym, w durkheimowskim tego słowa znaczeniu, nośnikiem pamięci chłopskiej.

Mimo tragedii, których Łukowski musiał być świadkiem, lub słyszeć o nich, fotograf nadal robił zdjęcia ślubów, wesel, pięknych dziewczyn, jakby wojny, takiej o jakiej uczymy się z podręczników i widzimy na wystawach przygotowanych przez historyków nie było, albo nie była istotna. Na fotografiach Łukowskiego życie toczy się dalej, odbywają się wesela, pogrzeby, ludzie się kochają i przyjaźnią mimo doświadczanych momentów okrucieństw. Ten wybór tematów można objaśnić słowami Stefana Czarnowskiego (1956, s. 84-85): „fakty zachodzące w życiu społeczności ludzkiej są z jednej strony zdarzeniami określonego przebiegu. [...] ale te same fakty mają jeszcze drugą stronę [...]. Każdy $z$ nich jest przejawem jednorazowym i mniej lub więcej cząstkowym określonego typu współżycia, jest wyrazem zewnętrznym pewnego układu wartości 
duchowych i materialnych, pewnej, zarówno psychicznej jak i fizycznej organizacji życia ludzkiego [...]. Układy te nie są identyczne $z$ układami zdarzeń. Stanowią one rzeczywistość społeczną wewnętrzną. Są normami współżycia ludzkiego, częściowo tylko wyrażającymi się w czynach, są czynów tych typem i uzasadnieniem. Badanie tej strony faktów wymaga innych metod niż badanie historyczne $\mathrm{w}$ rozumieniu potocznym. Chodzi tu nie o wyjaśnienie przyczynowe, ale o odtworzenie układu wartości”.

Zdjęcia Łukowskiego są nośnikiem tych „układów wartości”. Mieszkańcy Siemnic żyli według nich przed wojną, ale i w trakcie wojny nie uległy one zmianie. Odwolując się do koncepcji przyspieszenia historii i zerwania z przeszłością, którą sformułował Pierre Nora, można powiedzieć, że chociaż świat, w którym żyli mieszkańcy Siemnic, ulegał dramatycznym przemianom: wysiedlono część mieszkańców, przesiedlono Niemców z Besarabii, zabito żydowskich sąsiadów, reglamentowano żywność, śmierć groziła na każdym kroku, mimo wszystko wspólnota usilnie starała się zachować swój świat. Doskonałym dowodem na to są fotografie Łukowskiego, które przedstawiają właśnie zwyczajność. Jakby fotograf wierzył w sprawczość fotografii, że fotografia normalności zachowa samą normalność. Zdjęcia okresu okupacji nie stanowią zatem przykładu ilustracji końca pewnego okresu, ale są raczej próbą uchwycenia i zachowania wymiarów starego świata wartości. Dopiero zdjęcia z lat pięćdziesiątych pokazują zmianę świata. Na fotografiach Łukowskiego pojawiają się nowe widoki: pochody, stowarzyszenia wiejskie, nowe maszyny rolnicze $\mathrm{i}$ inne wcześniej nie istniejące wymiary życia wiejskiego:

O to zawdzięczam temu, Gierkowi, niech go Bóg weźmie do swojej chwaty, niech go naprawde, niech mu przebacza wszystko, niech go weźmie do siebie, że on te renty sie wystarat. To on to zrobit. [...], to wszystko Gierka praca. To wszystko Gierek, te szkoty, dachy, te o dachy, co teraz eternitem, teraz już kryja blacha, a te dachy byty wszędzie stoma kryte, snopki takie się robito! [...]. Gierek to zlikwidowat, te dachy. Tu [niezroz.] burza czy co, blysnęto, już sie palito, tak! I oni mówia, haa, on dużo zrobit! I Boże miej go w swojej opiece i daj mu naprawdę, weź go do siebie, bo to byt cztowiek naprawde $[\ldots][2 \mathrm{~K}]$.

Fotografie $z$ tego okresu stają się nośnikiem zmiany, pokazują zerwanie z przeszłością, rozumianą nie tylko jako pojawienie się dachów krytych eternitem i elektryfikacja, ale właśnie jako zerwanie ze zbiorowo pamiętanymi wartościami (Nora 2009, s. 4).

Brak uwiecznienia na negatywach pewnych wydarzeń z przeszłości nie wynika $z$ tego, że Łukowski nie przywiązywał do nich wagi, ale $z$ faktu, że jako fotograf chłopski, nosiciel swojej kultury fotografował to, co było dla niej ważne, godne zapamiętania i dotyczyło życia wspólnoty lokalnej. Pewnych widoków nie ma na zdjęciach Łukowskiego, by można było o nich zapomnieć. Pamięć chłopska dotyczy bowiem tego, co istotne dla grupy, a więc „życia”, a nie śmierci, stąd obecne na fotografiach śluby, dzieci, przyjaciele. Jak pisał Maurice Halbwachs, „grupa żyjąca nade wszystko sobą samą stara się utrwalić uczucia 
i wyobrażenia, które stanowią treść ich myśli. Najwięcej miejsca w jej pamięci zajmuje więc ten czas miniony, w którego trakcie nic nie uległo głębokiej zmianie [...]" (cyt. za: Szacki 2011, s. 237).

Każda pamięć zbiorowa przedstawia grupie jej własny obraz, ale wydaje się, że zwłaszcza w przypadku chłopów chodzi o taki obraz, w którym grupa rozpozna się w swych kolejnych wyobrażeniach. „Skoro grupa jest wciąż ta sama - twierdził Halbwachs (cyt. za: Szacki 2011, s. 237) - zmiany muszą być zmianami pozornymi: zmiany, to jest wydarzenia zachodzące w grupie, też roztapiają się w podobieństwach, gdyż ich rola zdaje się polegać na rozwijaniu od różnych stron tej samej treści czyli różnych cech podstawowych danej grupy". W rezultacie nawet jeśli Łukowski fotografował pogrzeb ofiar pacyfikacji czy zabitego przez niemieckich osadników Adolka Ślebodę, nie starał się nadać tym ujęciom cech wyjątkowości, podobnie jak w przypadku zwykłych pogrzebów fotografował konwój czy grupę żałobników. „Przeszłość - jak twierdził Ryszard Tomicki (1981, s. 362) — sakralizuje nie tyle historię społeczności, gdyż takowej ona nie posiada, ile jej ponad- czy pozaczasową teraźniejszość kulturową. Każdy element kultury, nawet stosunkowo nowy, ale zaakceptowany przez grupe, podlegał «synchronizacji» $z$ pozostałymi elementami poprzez odniesienie go w przeszłość [...], która "potwierdzając» jego wartość, czyniła go równocześnie integralnym składnikiem ex definitione niezmiennego porządku świata”. Zdjęcia Łukowskiego potwierdzają solidarność grupową i odwieczną zasadę konieczności grzebania zmarłych zgodnie z obrządkiem religijnym.

Skoro pamięć chłopska obejmuje własne doświadczenia i doświadczenia własnej grupy, nie powinno dziwić, że Łukowski tak chętnie robił zdjęcia swojej rodzinie i krewnym oraz że tak chętnie sam stawał się bohaterem fotografii. Historycy sztuki i medioznawcy tłumaczą to jako artystyczną autoprezentację, ale można to również odczytać właśnie jako chęć utrwalenia swojej obecności $\mathrm{w}$ wydarzeniach. Podobnie w przeprowadzonych przez nas wywiadach punktem referencyjnym stają się doświadczenia rozmówców, a nie poglądy uformowane przez media. Dlatego w ich opowieściach są dobrzy Niemcy, brakuje za to wielu faktów uznanych przez historyków za ważne, jak przyczyny ukraińskich mordów na Polakach, życie w cieniu obozu zagłady w Bełżcu czy świadomość, $\dot{z}$ e w ich regionie przechowywano Żydów. Te wydarzenia nie zostały zapisane w pamięci, gdyż nie dotyczą losów własnej grupy. Jednak nawet opowieści o własnej grupie są niekompletne, rozmówcy nie umieli opowiedzieć o wielu osobach widocznych na zdjęciach. Jest to efekt zarówno selektywności pamięci (pamięta się osoby, z którymi miało się styczność), jak i tego, że nie posiadająca mechanicznych środków utrwalania pamięci chłopska wiedza o przeszłości sięga w zasadzie wyłącznie okresu, który obejmują pamięcią najstarsi członkowie grupy (Tomicki 1981, s. 539).

Zdjęcia Feliksa Łukowskiego są takim „mechanicznym środkiem utrwalania pamięci", dlaczego zatem badacze mają taki problem ze zrozumieniem tych obrazów? Odpowiedź jest prosta — przyspieszenie historii sprawiło, że prze- 
stały one być dla nas czytelne. Uchwycone na negatywach Łukowskiego śluby, wesela, pogrzeby z czasów wojny są bowiem nośnikiem chłopskiego świata wartości, który przestał istnieć. Dodatkową trudnością jest fakt, że jesteśmy zewnętrznymi obserwatorami tego świata, który był społecznością zamkniętą i kompletną, a więc z zasady niedostępną dla obcych.

Spis wywiadów

\begin{tabular}{|c|c|c|c|}
\hline Rozmówca & Rok urodzenia & Miejsce & Data \\
\hline $1 \mathrm{~K}$ & 1940 & Krynice & lipiec 2015 \\
\hline $1 \mathrm{M}$ & 1925 & Wożuczyn & lipiec 2015 \\
\hline $2 \mathrm{~K}$ & 1927 & Wożuczyn & lipiec 2015 \\
\hline $3 \mathrm{~K}$ & 1939 & Wożuczyn & lipiec 2015 \\
\hline $4 \mathrm{~K}$ & 1930 & Wożuczyn & lipiec 2015 \\
\hline $5 \mathrm{~K}$ & 1928 & Wożuczyn Cukrownia & lipiec 2015 \\
\hline $2 \mathrm{M}$ & 1927 & Siemnice & lipiec 2015 \\
\hline $6 \mathrm{~K}$ & 1939 & Krynice & lipiec 2015 \\
\hline $3 \mathrm{M}$ & 1928 & Rachanie & lipiec 2015 \\
\hline $4 \mathrm{M}$ & 1931 & Rachanie & lipiec 2015 \\
\hline $5 \mathrm{M}$ & 1937 & Krynice & lipiec 2015 \\
\hline $7 \mathrm{~K}$ & 1938 & Krynice & lipiec 2015 \\
\hline $8 \mathrm{~K}$ & 1930 & Rachanie & lipiec 2015 \\
\hline $1 \mathrm{NN}$ & & Rachanie & lipiec 2015 \\
\hline $9 \mathrm{~K}$ & 1935 & Siemnice & lipiec 2015 \\
\hline $8 \mathrm{M}$ & 1946 & Wożuczyn & lipiec 2015 \\
\hline $9 \mathrm{M}$ & 1925 & Wożuczyn & lipiec 2015 \\
\hline $10 \mathrm{~K}$ & 1972 & Wożuczyn & lipiec 2015 \\
\hline $11 \mathrm{~K}$ & $1920 ?$ & Wożuczyn Cukrownia & lipiec 2015 \\
\hline $10 \mathrm{M}$ & 1928 & Siemnice & lipiec 2015 \\
\hline
\end{tabular}

\section{BIBLIOGRAFIA}

Alcaraz Łukaszewicz Aleksandra, 2014, Epistemologiczna rola obrazu fotograficznego, Scholar, Warszawa.

Ambrożewicz Teresa, 1985, Fotograf wiejski i jego świat. Wojciech Migacz 1874-1944. Katalog wystawy, Państwowe Muzeum Etnograficzne, Warszawa.

Banks Marcus, 2009, Materiały wizualne w badaniach jakościowych, tłum. Paweł Tomanek, Wydawnictwo Naukowe PWN, Warszawa.

Barthes Roland, 1995, Światło obrazu; Uwagi o fotografii, tłum. Jacek Trznadel, Wydawnictwo KR, Warszawa.

Bartuszek Joanna, 2005, Między reprezentacją a martwym papierem. Znaczenie i funkcja chtopskiej fotografii rodzinnej, Neriton, Warszawa.

Bartuszek Joanna, 2012, Fotografia - niemy obraz rzeczywistości. O problematyce identyfikacji zbiorów fotograficznych w kolekcji muzealnej, „Etnografia Nowa”, nr 4.

Becker Howard S., 2012, Socjologia wizualna, fotografia dokumentalna i fotografia reporterska: prawie wszystko zależy od kontekstu, w: Piotr Sztompka, Małgorzata Bogunia-Borowska (red.), Fotospoteczeństwo. Antologia tekstów z socjologii wizualnej, Znak, Kraków. 
Berger John,1999, O patrzeniu, tłum. Sławomir Sikora, Fundacja Aletheia, Warszawa.

Bourdieu Pierre, 2012, Spoteczna definicja fotografii, w: Piotr Sztompka, Małgorzata Bogunia-Borowska (red.), Fotospoteczeństwo. Antologia tekstów z socjologii wizualnej, Znak, Kraków.

Burszta Józef, 1976, Spoleczności lokalne, w: Etnografia Polski: przemiany kultury ludowej, t. 1, Maria Biernacka i in. (red.), Ossolineum, Wrocław.

Czarnowski Stefan, 1956, Dzieła, t. 5, Państwowe Wydawnictwo Naukowe, Warszawa.

Dowadall George, Golden John, 1990, Photographs as Data: An Analysis of Images from a Mental Hospital, „Qualitative Sociology, t. 12, nr 2, s. 183-213.

Edwards Elizabeth, 2001, Raw Histories: Photographs, Anthropology and Museums, Berg, Oxford.

Foucault Michel, 1998, Trzeba bronić spoteczeństwa: wykłady w Collège de France, 1976, tłum. Małgorzata Kowalska, Wydawnictwo KR, Warszawa.

Garlicka Aleksandra, 1993, Fotografia chtopów polskich, Krajowa Agencja Wydawnicza, Warszawa.

Geertz Clifford, 2005, Interpretacja kultur. Wybrane eseje, tłum. Maria M. Piechaczek, Wydawnictwo Uniwersytetu Jagiellońskiego, Kraków.

Geffroy Yannick, 1990, Family Photographs: A Visual Heritage, „Visual Anthropology”, t. 3, s. 367-410.

Gombrich Ernst, 1990, Obraz wizualny, w: Michał Głowiński (red.), Symbole $i$ symbolika, tłum. Grażyna Borkowska i in., Czytelnik, Warszawa.

Jaczyńska Agnieszka, 2012, Sonderlaboratorium SS. Zamojszczyzna — pierwszy obszar osiedleńczy w Generalnym Gubernatorstwie, IPN, Lublin.

Katalog wystawy, 1993, Antyfotografia i ciag dalszy. Beksiński, Lewczyński, Schlabs, Wrocław.

Katalog wystawy, 2005, Jerzy Lewczyński, Archeologia fotografi - prace z lat 1941-2005, Września.

Klukowski Zygmunt, 1947, Zbrodnie niemieckie na Zamojszczyźnie, GKBzNwP, Warszawa.

Kulik Adam Wiesław, 2005, Świat Feliksa Łukowskiego, w: Świat chatup, stodót i opłotków. Wieś w obiektywie Feliksa Łukowskiego z Siemnic, pow. Tomaszów Lubelski. Fotografie z lat 40. i 50. XX wieku, Muzeum Zamojskie, Zamość.

Kuwałek Robert, 2010, Obóz zagłady w Betżcu, Państwowe Muzeum na Majdanku, Lublin.

Lewczyński Jerzy, 1987, Feliks Łukowski zapomniany fotograf ziemi tomaszowsko-lubelskiej. Fotografia artystyczna na terenach pogranicza w latach 1945-1987. Materiaty z II Sympozjum w Szczecinie 13-15.11 .1987 , Szczecin.

Lewczyński Jerzy, 2005, Feliks Łukowski - fotograf ludzi i czasów, w: Świat chałup, stodót i optotków. Wieś w obiektywie Feliksa Łukowskiego z Siemnic, pow. Tomaszów Lubelski. Fotografie z lat 40. i 50. $X X$ wieku, Muzeum Zamojskie, Zamość.

Łuczewski Michał, 2012, Odwieczny naród. Polak i Katolik w Żmiacej, Wydawnictwo Naukowe Uniwersytetu Mikołaja Kopernika, Toruń.

Markiewicz Jerzy, 1967, Nie dali ziemi skąd ich ród. Zamojszczyzna 27 XI 1942-31 XII 1943, Wydawnictwo Lubelskie, Lublin.

Mędrzecki Włodzimierz, 1991, Fotografia chłopska jako źródło do dziejów rodziny chtopskiej w Królestwie Polskim na przetomie XIX $i$ XX wieku, w: Spoteczeństwo polskie XIX $i$ XX wieku, Warszawa, t. 9.

Michałowska Marianna, 2007, Obraz utajony. Szkice o fotografii i pamięci, Galeria F5 \& Księgarnia Fotograficzna, Kraków.

Mielcarz Beata, 2010, „Archeologia fotografii” - archeologia miasta, w: Marcin Lachowski, Piotr Majewski (red.), Obrazy miasta. Fotografia pomiędzy dokumentem a dzietem sztuki, Towarzystwo Naukowe Katolickiego Uniwersytetu Lubelskiego Jana Pawła II, Lublin.

Mielcarz Beata, 2012, Jerzy Lewczyński: droga życia - droga fotografii, w: Wiesław Łuczaj, Marek Świeca (red.), Media i nowe media, Wydawnictwo Uniwersytetu Jana Kochanowskiego, Kielce.

Nora Pierre, 2009, Między pamięcią i historia, les lieux de memoire, „Archiwum”, nr 2, s. 4-12.

Olechnicki Krzysztof, 2003, Obrazy $w$ dziataniu — obrazy $w$ badaniu, w: Krzysztof Olechnicki (red.), Obrazy w działaniu: studia $z$ socjologii $i$ antropologii obrazu, Wydawnictwo Uniwersytetu Mikołaja Kopernika, Toruń. 
Porter Gaby, 1988, The Economy of Truth, Photography in Museums, „Ten/8, 34”, Autumn, s. 20-33. Sikora Sławomir, 2004, Między przezroczystościa a nieprzezroczystością: aporia fotografii, w: Grzegorz Pełczyński, Ryszard Vorbrich (red.), Antropologia wobec fotografii i filmu, Biblioteka Telgte Wydawnictwo, Poznań.

Sontag Susan, 1986, O fotografii, tłum. Sławomir Magala, Wydawnictwo Artystyczne i Filmowe, Warszawa.

Struk Janina, 2007, Holokaust $w$ fotografiach, Interpretacje dowodów, Prószyński i S-ka, Warszawa. Szacki Jerzy, 2011, Tradycja, Wydawnictwa Uniwersytetu Warszawskiego, Warszawa.

Sztandara Magdalena, 2006, Fotografia etnograficzna i etnograficzność fotografii. Studium z historii myśli etnograficznej i fotografii II pot. XIX i I pot. XX wieku, Wydawnictwo Uniwersytetu Opolskiego, Opole.

Szymańczuk J., 1992, Jestem fotografem, „Konteksty. Polska Sztuka Ludowa”, nr 3-4.

Tomicki Ryszard, 1981, Kultura — dziedzictwo - tradycja, w: Etnografia Polski: przemiany kultury ludowej, t. 2, Maria Biernacka i in. (red.), Ossolineum, Wrocław.

Wright Terence, 1997, Fotografia: teorie realizmu $i$ konwencji, „Konteksty. Polska Sztuka Ludowa”, nr 3-4.

\section{PEASANT MEMORY OF THE WAR AND THE PHOTOGRAPHY OF FELIKS ŁUKOWSKI}

\section{Summary}

The author considers selected photography of the amateur photographer Feliks Łukowski, from the period of the Second World War. The photos were taken in Łukowski's native village and in nearby localities during the German occupation. They are presented with the results of field research conducted in July 2015 in the Zamojść area in order to show how what is remembered by witnesses departs from what was captured in the photos. The author attempts to explain the source of that divergence and also to show how useful a sociological analysis of photography can be in determining the meanings produced by the images it preserves. The aim of these reflections is to emphasize the characteristic traits and functioning of peasant memory.

\section{Key words / słowa kluczowe}

Feliks Łukowski; photography / fotografia; visual sociology / socjologia wizualna; peasant memory / pamięć chłopska; Zamość region / Zamojszczyzna; Holocaust / Zagłada 